\title{
Determination of Evapotranspiration and Annual Biomass Productivity of a Cactus Pear [Opuntia ficus-indica L. (Mill.)] Orchard in a Semiarid Environment
}

\author{
S. Consoli ${ }^{1}$; G. Inglese, Ph.D. ${ }^{2}$; and P. Inglese ${ }^{3}$
}

\begin{abstract}
A micrometeorological approach based on the surface energy balance was adopted to estimate evapotranspiration fluxes and crop coefficient data from an irrigated cactus pear [Opuntia ficus-indica L. (Mill.)] orchard under Mediterranean climatic conditions. Highfrequency temperature readings were taken above the canopy top to get sensible heat flux values $\left(H_{\mathrm{SR}}\right)$ using the surface renewal technique. These values were compared against eddy covariance sensible heat fluxes $\left(H_{\mathrm{EC}}\right)$ for calibration. Latent heat flux (or evapotranspiration, ET) was obtained by solving the daily energy balance equation. Measurements of soil hydraulic components were integrated with the analysis of the surface energy fluxes and crop development in terms of phenology and aboveground biomass accumulation. Microlysimeters were used to compute evaporation rates, allowing the separation of daily transpiration from ET data. Ecophysiological measurements were carried to estimate dry weight accumulation and partitioning. Cactus pear evapotranspired a total of approximately 286 and $252 \mathrm{~mm}$ of water during the two monitored growing seasons, respectively. Average daily values of crop $\left(\mathrm{ET}_{c}\right)$ and reference $\left(\mathrm{ET}_{0}\right)$ evapotranspiration were in the order of 2.5 and $5.0 \mathrm{~mm}$, respectively, with a corresponding value of the mean crop coefficient of approximately 0.40 . The annual dry mass fixed per single tree was $38.8 \pm 1.3 \mathrm{~kg}$, with a total production of $12.9 \mathrm{tha}^{-1}$, which is comparable to many $C_{3}$ and $C_{4}$ plants and resulted in a water use efficiency (WUE) of 4.6 and $4.4 \mathrm{~g} \mathrm{DM} \mathrm{kg} \mathrm{H}_{2} \mathrm{O}^{-1}$ in 2009 and 2010, respectively. The stem area index (SAI) was 3.5. DOI: 10.1061/ (ASCE)IR.1943-4774.0000589. ( 2013 American Society of Civil Engineers.
\end{abstract}

CE Database subject headings: Evapotranspiration; Crops; Coefficients; Water use; Arid lands.

Author keywords: Crassulacean acid metabolism (CAM) species; Energy balance; Crop coefficient; Water use efficiency.

\section{Introduction}

Cactus pear [Opuntia ficus-indica L. (Mill.)] is a succulent species with a crassulacean acid metabolism (CAM) system. Its native area is Mexico, and it is cultivated for fruit production. It is also found in the Mediterranean basin and in semiarid zones of North and South America and Africa. It is also used as a vegetable and for cattle fodder and forage production (Nobel 2002). In these regions, rainfall distribution is a critical limiting factor, as are extensive and variable dry seasons, high soil-water deficit conditions, and a dry atmosphere. O. ficus-indica (OFI) thrives in areas with restricted water supply (200 or $300 \mathrm{~mm}$ of annual rainfall) or where long periods of drought occur because of the ecological advantage related to the daily timing of stomata opening. In fact, OFI plants open the stomata during the night, when lower temperature

\footnotetext{
${ }^{1}$ Associate Professor, Dept. of Agri-food and Environmental System Management, Univ. of Catania, Via S. Sofia 100 - 95123 Catania, Italy (corresponding author). E-mail: simona.consoli@unict.it

${ }^{2}$ Dept. of Forest and Agricultural Science, Univ. of Palermo, V.le delle Scienze, Palermo 90128, Italy. E-mail: guinglese@gmail.com

${ }^{3}$ Full Professor, Dept. of Forest and Agricultural Science, Univ. of Palermo, V.le delle Scienze, Palermo 90128, Italy. E-mail: paolo .inglese@unipa.it

Note. This manuscript was submitted on September 18, 2012; approved on January 31, 2013; published online on February 2, 2013. Discussion period open until January 1, 2014; separate discussions must be submitted for individual papers. This paper is part of the Journal of Irrigation and Drainage Engineering, Vol. 139, No. 8, August 1, 2013. (C) ASCE, ISSN 0733-9437/2013/8-680-690/\$25.00.
}

and water pressure deficit account for a lower evaporative demand than during daytime, leading to a twofold to sixfold lower transpiration rate compared with the same degree of stomata opening during the day (Nobel 1988; San José et al. 2007a). Ultimately, the water use efficiency (WUE) of the species reaches values of approximately 3.3-4.0 g dry matter $\mathrm{kg} \mathrm{H}_{2} \mathrm{O}^{-1}$ (De Kock 1980; Le Houèrou 2000).

Nobel and Hartsock (1984) showed that 3 weeks of drought are required for halving net $\mathrm{CO}_{2}$ uptake of Opuntia ficus-indica over 24-h periods, and after 50 days of drought net $\mathrm{CO}_{2}$, the uptake of cladodes (stemlike flattened organs) is around zero (Acevedo et al. 1983). Moreover, 3 months of drought decreased nocturnal acid accumulation by $73 \%$, essentially abolished transpiration, and reduced cladode water content by $45 \%$ (Goldstein et al. 1991). Nevertheless, when Opuntia ficus-indica is cultivated for fruit production, fruit size is reduced by water deficit long before the tree shows any symptom of water stress (Gugliuzza et al. 2002).

Indeed, in the Mediterranean basin, most of the fruit development period coincides with long and dry summers, with a water deficit period that may last for 3-4 months (June-September). In these conditions, an annual volume of $60-100 \mathrm{~mm}$ of irrigation water, during the fruit development period, is required with fruit thinning to get export-size fruit with regular flesh percent (55-65\%) and to increase marketable yield composition (Barbera 1984; Gugliuzza et al. 2002). Nerd et al. (1989) reported that in the Negev desert, where the annual rainfall is lower than $300 \mathrm{~mm}$, winter irrigation regulates plant fertility and spring burst timing during springtime. However, timing and applied volumes are still 
defined on an empiric basis, and no data are available on water requirements of cactus pear orchard for fruit production. So far, evapotranspiration (ET) rates of cacti have been evaluated using the soil water balance (SWB) technique (Han and Felker 1997; Snyman 2006), which includes the additional component called plant water content change because cacti can store a large amount of water in its aboveground part. The application of SWB techniques through soil water flow models can simulate the performance of various irrigation designs and can evaluate specified objectives such as stress management. The most recent technical advances on SWB models include more rigorous treatment of multidimensional soil water flow models and the temporal pattern of root water uptake (Consoli and Barbagallo 2012). The complexity of parameters needed to describe multidimensional root water uptake in heterogeneous media represents a severe constraint for the application of the modeling approaches.

Other studies (Nobel and Bobich 2002; San José et al. 2007a, b) carried out on CAM communities have reported the use of micrometeorological techniques to evaluate the diurnal pattern of water vapor and energy fluxes exchanged within the soil-plantatmosphere continuum. In these studies, micrometeorological approaches provided a suitable mean to determine crop ET because CAM species (i.e., cactus pear, pineapple) growth can affect surface forcing conditions and partitioning of available energy into sensible $(H)$ and latent ( $\lambda E$ or ET) heat flux densities. In this respect, micrometeorological approaches are of particular interest because of their ability to predict surface control of energy transfer in terms of canopy and environmental factors (Jarvis and McNaughton 1986). Among the micrometeorological techniques, the most commonly adopted in the applied research are the sonic eddy covariance method (Simmons et al. 2007), the surface renewal (SR) method (Spano et al. 1997), and large aperture scintillometry (Meijninger and de Bruin 2000). Sonic eddy covariance (SEC) is considered as the reference micrometeorological technique to directly measure the latent heat and $\mathrm{CO}_{2}$ fluxes. It is based on the use of high frequency $(10 \mathrm{~Hz})$ measurements of the three components of wind speed by means of sonic anemometers and concentrations of water vapor and $\mathrm{CO}_{2}$ by means of fast optical gas analyzers. These measurements are interpreted by considering the equations of turbulence in the atmospheric boundary layer (Foken 2008). Sonic eddy covariance has been intensively used in several locations around the world to monitor mass and energy exchanges in the soil-plant-atmosphere continuum, even in remote locations and for long time intervals. However, SEC systems are quite complex to operate, and several simpler alternative methods have been developed in the context of water management, such as the SR (Paw U et al. 1995; Snyder et al. 1996). The SR method is based on the concept of eddy accumulation (conditional sampling) and on the analysis of ramp structure in the temperature field above the canopy. The method allows the estimation of sensible heat fluxes within the plant-atmosphere system, and results are easier to apply with respect to SEC (Snyder et al. 1996)

Within this context of research, the objectives of the study were (1) to evaluate the suitability of the surface renewal technique combined with the energy balance equation to estimate daily evapotranspiration and crop coefficient for a cactus pear orchard over two years (2009-2010), and (2) to evaluate the annual aboveground dry matter accumulation, the stem area index, and the water use efficiency for a cactus pear orchard for commercial fruit production during 2009. To accomplish these objectives, energy flux densities were directly measured or estimated over a cactus pear orchard in Sicily from spring burst in 2009 to fruit harvest in autumn 2010 over two cropping seasons.

\section{Materials and Methods}

\section{Site Description}

The study was carried out at the experimental field of Roccapalumba $\left(37^{\circ} 48^{\prime} \mathrm{N}, 13^{\circ} 38^{\prime} \mathrm{E}\right.$, altitude $350 \mathrm{~m}$ above sea level), western Sicily, Italy, from June 2009 to September 2010, over two cropping seasons. The semiarid climate of the area was characterized by a mean annual precipitation of approximately $550 \mathrm{~mm}$ (with $28 \%$ of variation during 1971-2010). Most rainfall occurred from November to March/ April, with a dry period that usually lasted from June throughout September. Mean monthly temperatures ranged from approximately $9^{\circ} \mathrm{C}$ in February to $30^{\circ} \mathrm{C}$ in August, with maximum daily temperatures reaching $35^{\circ} \mathrm{C}$ in July-August (Table 1).

The experiment was set in an orchard made of 10-year-old cactus pear trees of Gialla (90\%), Rossa (8\%), and Bianca (2\%) cultivars, trained to a globe shape. The orchard was large enough, $3.5 \mathrm{ha}$, to have the footprint of the flux measurements within the experimental area. The orchard was established by placing single cuttings on each hole along north-south oriented rows. The trees were trained to reach a maximum height of $3 \mathrm{~m}$ and were spaced $5 \times 6 \mathrm{~m}$ apart (333 trees ha ${ }^{-1}$ ). The fraction of soil area covered by cactus pear canopies was approximately $65 \%$, considering that trees were formed as a continuous hedge along the row and covered $2 / 3$ of the alley. Ordinary horticultural care included the removal, during the first week of June, of the spring flush of flowers and current-year cladodes. Based on a 10-year-long data set, the annual marketable fruit production was $18.0 \mathrm{tha}^{-1}$.

The irrigation system consisted of one microsprinkler line per row, with four on-line sprayers per tree, with a flow rate of $401 \mathrm{~h}^{-1}$ per sprayer at a pressure of $150 \mathrm{kPa}$. Trees were fully irrigated

Table 1. Main Climatic Features Observed at the Cactus Field of Roccapalumba during the Experiment and $\mathrm{ET}_{0}$ Data

\begin{tabular}{lrrrcc}
\hline Month & Rain $(\mathrm{mm})$ & $T_{a}\left({ }^{\circ} \mathrm{C}\right)$ & $u(\mathrm{~m} / \mathrm{s})$ & $\mathrm{RH}(\%)$ & $\mathrm{ET}_{0}\left(\mathrm{~mm} \mathrm{~d}^{-1}\right)$ \\
\hline 2009 & & & & & \\
January & 33.0 & 10.5 & 0.5 & 87.4 & 20.3 \\
February & 23.6 & 9.2 & 0.8 & 85.2 & 35.5 \\
March & 39.6 & 12.4 & 0.9 & 68.4 & 68.4 \\
April & 56.0 & 20.8 & 2.7 & 55.8 & 92.5 \\
May & 25.6 & 18.7 & 2.1 & 68.2 & 128.1 \\
June & 4.6 & 23.0 & 1.9 & 67.8 & 166.8 \\
July & 8.2 & 27.2 & 1.7 & 59.8 & 211.9 \\
August & 32.2 & 27.4 & 1.8 & 60.4 & 173.4 \\
September & 75.0 & 23.8 & 1.8 & 79.9 & 104.7 \\
October & 120.0 & 17.6 & 1.8 & 84.0 & 55.9 \\
November & 134.2 & 14.7 & 1.7 & 81.2 & 44.8 \\
December & 140.8 & 11.9 & 0.5 & 87.0 & 17.9 \\
2010 & & & & & \\
January & 117.5 & 9.2 & 0.8 & 84.0 & 36.1 \\
February & 114.5 & 9.0 & 0.8 & 83.8 & 53.4 \\
March & 44.6 & 11.2 & 0.8 & 84.2 & 81.1 \\
April & 77.4 & 19.3 & 1.6 & 60.0 & 105.5 \\
May & 0.0 & 17.6 & 1.9 & 59.2 & 144.4 \\
June & 30.8 & 23.0 & 2.3 & 60.0 & 154.8 \\
July & 0.0 & 26.0 & 1.9 & 58.2 & 182.2 \\
August & 0.0 & 26.5 & 1.9 & 58.2 & 180.5 \\
September & 64.3 & 19.5 & 1.9 & 74.1 & 103.3 \\
October & 35.0 & 18.9 & 1.6 & 87.6 & 58.5 \\
November & 79.4 & 17.0 & 1.8 & 84.8 & 74.3 \\
December & 104.4 & 12.9 & 0.9 & 82.5 & 52 \\
\hline Note: & & & & \\
\hline
\end{tabular}

Note: Months-period average were determined using half-hourly values for the measurements; $T_{a}=$ mean daily air temperature; $u=$ wind speed; $\mathrm{RH}=$ relative air humidity; rain and $\mathrm{ET}_{0}=$ total precipitation and reference evapotranspiration, respectively. 
throughout the experiment, following routine horticultural care, based on the farmer's decision. A total of 120 and $148 \mathrm{~mm}$ of water was distributed during 2009 and 2010, respectively, from June throughout September, and irrigation frequency ranged from 1 week, from the first week of June to full bloom in July, to 4 days during the fruit development period, until the last week of September. Decisions on irrigation scheduling were, generally, taken by the farmer according to tensiometer readings; such devices were used to measure the pressure potential of the soil. During the years of the study in the cactus pear stand, the farmer's decision on irrigation scheduling gradually followed the evapotranspiration regime (obtained by the micrometeorological study) of the orchard. However, irrigation volumes and irrigation timing were, strictly, dependent on water availability at the field and the farmer's own decision to operate the water regime in the orchard (i.e., related to the plant water status and leaf angles).

According to USDA classification [Soil Conservation Service (SCS) 1982], the soil at the experimental site had a clay-loam texture with $40 \%$ sand, $38 \%$ clay, and $22 \%$ silt. To determine soil hydraulic characteristics, 10 undisturbed soil samples were collected (using stainless steel cylinders of $10^{-4} \mathrm{~m}^{3}$ inner volume) along a transversal transect at approximately 0.15 and $0.30 \mathrm{~m}$ deep. In the laboratory, the hydraulic conductivity at saturation $\left(k_{S}\right)$, determined with the falling-head method by a permeameter (Klute and Dirksen 1986), was $10^{-5} \mathrm{~m} \mathrm{~s}^{-1}$. Moisture contents at standard water potential values were determined by a sandbox and a pressure membrane apparatus (Van Genuchten's 1980; Mualem 1986). Saturated soil water content was $0.489 \mathrm{~m}^{3} \mathrm{~m}^{-3}$ and field capacity and wilting point were 0.357 and $0.15 \mathrm{~m}^{3} \mathrm{~m}^{-3}$, respectively. The soil bulk density was of $1.2 \mathrm{~g} \mathrm{~cm}^{-3}$, typical of alluvial soil with narrow pores. A direct measurement of soil water content was made using the time domain reflectometry theory (TDR) (CS 616, Campbell Scientific, Logan, Utah). The probes were calibrated for the specific soil physical characteristics, i.e., the range of soil moisture between the field capacity and wilting point. Ten probes were placed at different depths from $15-60 \mathrm{~cm}$ and at different distances from the microsprinklers to evaluate the possible variation of soil moisture from wet (close to the emitter) to dry (at the middle of the space between emitters within each row). According to the measurements, each irrigation wetted the soil up to $1.00 \mathrm{~m}$ away from the emitter, to a depth of $40 \mathrm{~cm}$. The probes placed beyond this point did not register any effect of irrigation. These probes did register a continuous decrease in soil moisture throughout the season.

The soil moisture measurements described the evolution of the water content in the studied soil and established the soil volume from which the cactus trees were extracting water.

The extent of the water applied by the microsprinklers that evaporated before reaching the soil may have constituted a significant contribution to evaporation (5-20\%) depending on temperature, wind speed, air humidity, system pressure, and orifice size. In this case, the irrigation line was placed along the rows and below the canopies; all irrigation treatments were made during the early hours of the morning, when temperatures were low and air relative humidity (RH) was highest. Most of the wetted area was shaded by the canopy cover, so that a 5\% evaporation loss was considered. At the beginning of each experiment, system emission uniformity (EU) $(\%)$ values were determined according to Keller and Karmeli (1975), showing EU coefficients higher than $90 \%$.

\section{Aboveground Dry Matter Accumulation}

In 2009, annual aboveground dry matter accumulation was determined on six Gialla single trees randomly selected along three rows in the middle of the orchard. Trees had a uniform crop load and canopy development and received routine horticultural care. The annual vegetative growth was represented by the new flush of cladodes, flowers, and fruits, plus the increase in dry matter in the elder cladodes. During the first week of June 2009, all the new cladodes and flowers were detached to promote a return bloom. All harvested cladodes and flowers were weighed to obtain their fresh weight. A sample of 50 removed cladodes and flowers was weighted to determine their fresh weight and dried to constant weight in a forced-air oven at $70^{\circ} \mathrm{C}$. Total dry mass of removed flowers and cladodes was then calculated. At commercial harvest time, fruit from each tree was harvested, counted, and weighted. Fruit dry mass was calculated from a sample of 100 fruits dried to constant weight in a forced-air oven at $60^{\circ} \mathrm{C}$. At the end of the growing season, in November 2009, the second flush of currentyear cladodes in each tree was harvested, counted, and weighed. Fifty current-year cladodes, collected by each of the six trees, were weighed immediately after being detached from the trees, and then dried at $60^{\circ} \mathrm{C}$ to constant weight for dry mass determination. Dry weight accumulation during the season in 1, 2, 3, and 4-year-old cladodes was estimated from 15 samples for each cladode age, taken at the beginning (May) and the end (November) of the season with a cork borer $(1.0 \mathrm{~cm}$ in diameter $)$, and then dried to constant weight in a forced-air oven at $70^{\circ} \mathrm{C}$.

In December 2009, three trees were completely destroyed, and every single cladode was measured in terms of length, width, thickness, and weight. The area of both sides of a cladode $\left(\mathrm{cm}^{2}\right)$ was calculated from $\mathrm{SA}=0.8571 \cdot D L+0.3652\left(R^{2}=0.97\right)$, where SA is the surface area of the cladode, and $D$ and $L$ are cladode width and length in centimeters, respectively (Inglese et al. 1999). The regression derived from projected areas of 25 cladodes of each age, measured with a leaf area meter (Delta-T Devices LTD, Cambridge, UK). The dry mass increase of 1, 2, 3, and 4-year-old cladodes was then determined by upscaling the dry weight increase from May to November, measured in the cork borer samples to the calculated cladode surface area. The stem area index (SAI) was calculated as the ratio between the surface area of all photosynthetic cladodes, excluding lignified cladodes older than 4 years, and the ground area allotted to the tree resulting from planting distances.

Evapotranspiration water use efficiency $\left(\mathrm{WUE}_{\mathrm{ET}}\right)$ was defined as the ratio between the biomass (grams of dry matter of fruit + current-year cladodes + dry weight accumulation in elder cladodes) accumulated in the canopy and crop ET (Han and Felker 1997) determined as reported in the following sections.

\section{Micrometerological Measurements}

\section{SR Analysis}

In this study, SR was used to estimate the sensible heat flux density over the cactus pear orchard from June 2009 to September 2010. This analysis for estimating scalar surface fluxes used the SR theory [pioneered by Higbie (1935)] in conjunction with the analysis of the scalar trace (air temperature) to extract the mean dimensions (amplitude and period) of the ramplike (or asymmetric triangle shape) pattern observed in the trace (typically, half-hourly) (Fig. 1). Ramp dimensions identified a coherent structure that can be defined as an eddy capable of providing organization within the turbulent motion and responsible for the main vertical turbulent mixing (Paw U et al. 1995). The SR method was based on a solution of the scalar conservation equation for an incompressible steady and planar homogeneous turbulent flow. Sensible heat flux, assuming that the air parcel renewed (i.e., associated with the coherent structure) is uniformly heated (cooled) with no heat lost 


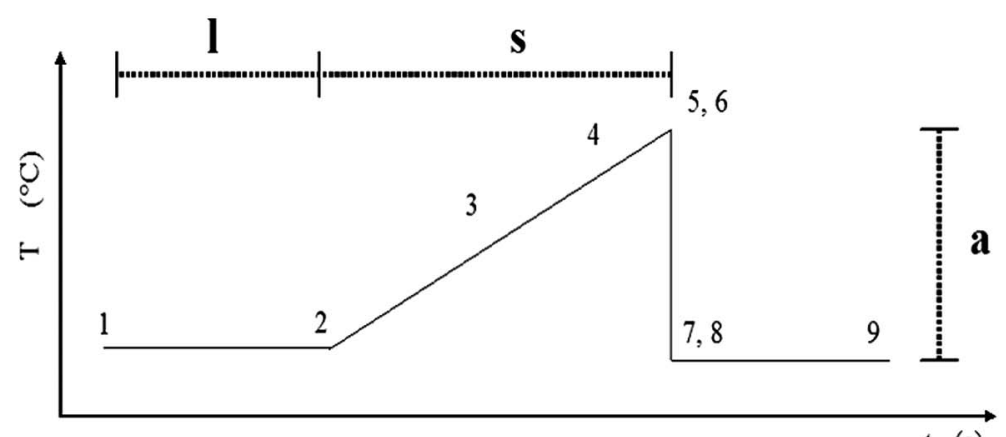

t (s)

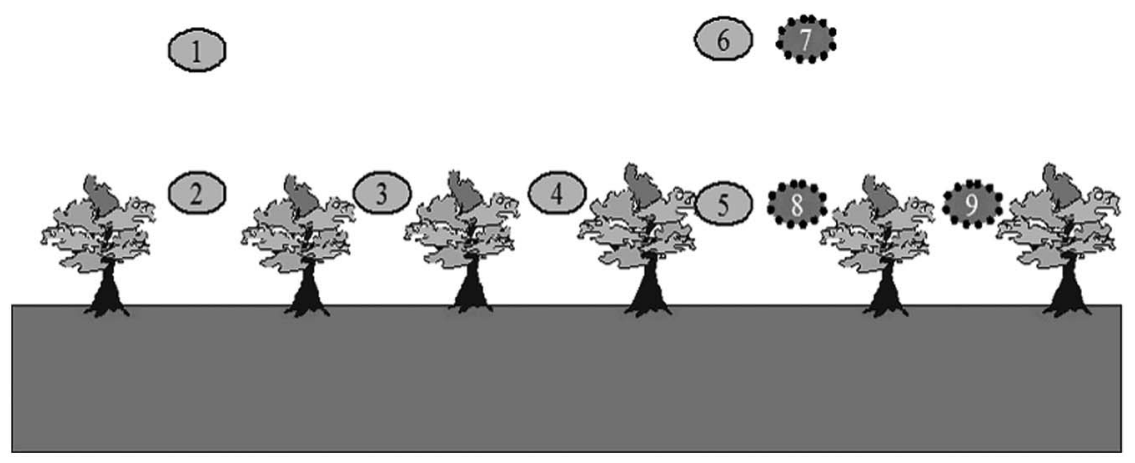

Fig. 1. Diagram of a coherent motion; time course of the scalar concentration for the positions shown in the diagram is idealized in a ramp model in which $l$ and $s$ denote the quiescent and warming periods, respectively; $a$ is the ramp amplitude (positive and negative for unstable and stable cases, respectively); and $\tau=l+s$ is the total ramp duration

through the parcel top while it remains in contact with the sources (sinks), can be estimated as (Paw U et al. 1995)

$$
H_{\mathrm{SR}}=\rho C_{p}(\alpha z) \frac{a}{\tau}
$$

where $\rho\left(\mathrm{Kg} \mathrm{m}^{-3}\right)$ and $C_{p}\left(\mathrm{~J} \mathrm{~kg}^{-1}{ }^{\circ} \mathrm{C}^{-1}\right)=$ density and specific heat at constant pressure of air, respectively; $z(\mathrm{~m})=$ measurement height of the air temperature trace that represents the volume, $V$, per unit area, $S$, of the parcel (i.e., $z=V / S$ ); $\alpha$ corrects the volume for the unequal heating within the air parcel; and $a\left({ }^{\circ} \mathrm{C}\right)$ and $\tau(s)=$ mean amplitude and period of the ramp pattern observed in the temperature trace, respectively. Because the SR method assumed parameter $\alpha$ as a constant to be calibrated against the EC method, the implication was sound because the only input required is the measurement of the air temperature trace at one height above the source.

Ramp dimensions were determined as described in Van Atta (1977) using structure functions $S_{(r)}^{n}$ ( $r$ denotes time lag) of order $n=2,3$, and 5. For solving the ramp period, several time lags were used to linearize the following relationship that holds for $r$ much smaller than the warming (cooling) period, $L_{r}$, while the air parcel to be renewed remains in contact with the surface

$$
a^{3}=-\frac{S_{(r)}^{3}}{r} \tau
$$

For the SR method, once $\alpha$ is known, determination of $H$ is immediate from measurements taken with a fine-wire thermocouple.

The described original SR method thus requires calibration of one parameter, the so-called parameter $\alpha$ [see Eq. (1)]. However, the assumption to take $\alpha$ as a constant appeared stringent because earlier studies showed dependency on stability cases, canopy architecture, and measurement height (Castellví 2004; Castellví et al. 2012). A new method, SR2, to estimate $\alpha$ (half-hourly) was derived that was capable of explaining the performance observed in previous experiments (Castellví 2004; Castellví et al. 2012). Method SR2 requires as input air temperature measured at high frequency, the mean and turbulent standard deviation of the horizontal wind speed, the leaf area index, the canopy height, and the vertical extent (m) of the foliage. Castellví et al. (2012) concluded that the $\alpha$ procedure used in SR2 can be considered a general application because it accounts for variability of the roughness sublayer depending on weather conditions and canopy characteristics. In the present paper, the original SR method was adopted because of the shorter data sets available for model (original SR and SR2) comparisons, the complex heterogeneous CAM stand, and the lack of studies on SR application on CAM communities.

To apply the SR method, two fine-wire thermocouples $(76 \mu \mathrm{m}$ diameter) were used to measure high frequency $(4 \mathrm{~Hz})$ temperature fluctuations. They were mounted $0.5 \mathrm{~m}$ above the canopy top (at $3.5 \mathrm{~m}$ from soil surface), and SR estimates of $H$ were computed using the mean ramplike temperature trace characteristics. Sensible heat flux data from the $\mathrm{SR}$ technique $\left(H_{\mathrm{SR}}, \mathrm{W} \mathrm{m}{ }^{-2}\right)$ were calibrated with independent eddy covariance (EC) measurements of $H_{\mathrm{EC}}$ by one three-dimensional (3D) sonic anemometer (Windmaster Pro, Gill Instruments Ltd, UK) located $3.5 \mathrm{~m}$ from the soil surface. The calibration data subset was used to derive the $\alpha$ value of Eq. (1) by simple linear regression forced through the origin. For this regression, $H_{\mathrm{EC}}$ was the dependent and $H_{\mathrm{SR}}$ was the independent variable. In this way, the regression slope provided the $\alpha$ value to estimate $H_{\mathrm{EC}}$ from the uncalibrated SR analysis. The eddy covariance sonic anemometer collected the high-frequency measurements $(10 \mathrm{~Hz})$ of the three wind components and virtual air temperature. Wind components were rotated to force the mean vertical wind speed fluctuations to zero and to align the horizontal wind speed to the mean streamwise direction (Kaimal and Finningan 1994). The net radiation (CNR1, Kipp and Zonen, Nebraska), $R_{n}$, was 
measured at $z=6 \mathrm{~m}$, and the averaged soil heat flux, $G$, was determined (Fuchs and Tanner 1967) using four soil heat flux plates (HFP01, Campbell Scientific) — two in a row (sunny area) and two below the canopy (shaded area).

The micrometeorological data set used for comparison included samples (of high and low frequency data) that passed the Foken's quality control test up to level 7 (Mauder and Foken 2004). The test checked the assumptions of steady flow and developed turbulence invoked in the EC method. Up to level 7 (i.e., from 1-7), the data set included high-quality flux measurements recommended for research purposes (up to level 3) and measurements that could be considered useful for routine applications and gap filling (from 4-7).

When ET is considered under the form of latent heat flux density $(\lambda E)$, it is worth considering all the energetic components acting above a vegetated surface, i.e., the energy balance, which can be written as

$$
\lambda E=R_{n}-G-H
$$

where all the terms are in $\mathrm{W} \mathrm{m}^{-2} ; R_{n}=$ net resulting from the balance of all the radiations above the crop and is directly measurable; $G=$ flux of heat in the soil; and $H=$ flux of sensible heat that was determined in the study from the application of the SR technique.

Several studies have reported that when cactus temperatures are directly measurable in the field, parts of the cactus stem facing the sun are found to be up to approximately $10^{\circ} \mathrm{C}$ above the air temperature. Parts facing away from the sun can be below air temperature, and time lags of a few hours are observed in the heating of the center of the stem (Nobel 2005). Consumption or production of energy by metabolic processes (Misc, i.e., miscellaneous flux densities attributable to the biochemical processes) can generally be ignored in the energy balance of crops, because it is a very small part of net radiation. An interesting exception occurs for many members of the CAM species, such as the barrel-shaped Ferocactus acanthodes and the tall, columnar Carnegiea gigantea (saguaro). In particular, the heat storage by cactus (Misc), related to the aforementioned temperature increase, can be estimated as follows:

$$
\text { Misc }=C_{v h} V \frac{\Delta T}{\Delta t}
$$

where $C_{v h}\left(\mathrm{~J} \mathrm{~m}^{-3}{ }^{\circ} \mathrm{C}^{-1}\right)=$ volumetric heat capacity, generally considered $70 \%$ as large as that of water at $25^{\circ} \mathrm{C} ; V(\mathrm{~m})=$ specific volume of a plant having a total surface area $A$ (i.e., the mean depth for heat storage); and $\Delta T=$ change in temperature $\left({ }^{\circ} \mathrm{C}\right.$, difference between crop temperature and air temperature) in the time interval $\Delta t$. In the study, the term Misc was computed, and accordingly Eq. (3) was modified as follows:

$$
\lambda E=R_{n}-G-H-\text { Misc }
$$

Crop ET $\left(\mathrm{ET}_{c}\right)$ was computed by dividing $\lambda E$ by the latent heat of vaporization: $\lambda=2.45 \mathrm{MJ} \mathrm{m}^{-2} \mathrm{~mm}^{-1}$.

The single crop coefficient approach (Allen et al. 1998) was used to determine $K_{c}$ values from crop $\mathrm{ET}_{c}$ and reference $\mathrm{ET}_{0}$.

$$
\mathrm{ET}_{c}=K_{c} \cdot \mathrm{ET}_{0}
$$

where $\mathrm{ET}_{0}=$ standardized reference evapotranspiration calculated using a modified Penman-Monteith equation (Allen et al. 2006)

$$
\mathrm{ET}_{0}=\frac{0.408 \Delta\left(R_{n}-G\right)+\gamma\left[C_{n} /(T+273)\right] u_{2}\left(e_{s}-e_{a}\right)}{\Delta+\gamma\left(1+C_{d} u_{2}\right)}
$$

The variables utilized in the formulation of $\mathrm{ET}_{0}$ are net radiation $\left(R_{n}\right)$, heat flux into the soil $(G)$, air density $\left(\rho_{a}\right)$, specific heat of air $\left(c_{p}\right)$, vapor pressure deficit $\left(e_{s}-e_{a}\right)$, the thermodynamic psychrometric constant $(\gamma)$, aerodynamic resistance $\left(r_{a}\right)$, canopy resistance $\left(r_{c}\right)$, air temperature $(T)$, wind speed adjusted to $2 \mathrm{~m}$ of height $\left(u_{2}\right)$, and saturation slope vapor pressure curve at air temperature $(\Delta)$. The coefficients $C_{n}$ and $C_{d}$ differ with calculation step. Values for $C_{n}$ and $C_{d}$ are presented in Allen et al. (2006). The required meteorological parameters, i.e., wind speed and vapor pressure deficit, were measured with an automatic weather station managed by the Sicilian Agrometerological Service (SIAS) and located $10 \mathrm{~km}$ away from the field experiment. The hourly $\mathrm{ET}_{0}$ values $\left(C_{n}=37\right.$ and $\left.C_{d}=34\right)$ were summed over $24 \mathrm{~h}$ to obtain daily $\mathrm{ET}_{0}$

\section{Climatic Features at the Experimental Field and Soil Evaporation Data}

The cactus pear stand was equipped with an automatic weather station to measure the values of ancillary meteorological features. In particular, low frequency (10-30 min) measurements were taken for air temperature and humidity at approximately $2 \mathrm{~m}$ above the canopy top (HMP45C Vaisala, Campbell Scientific). Wind speed (05103 RM Young), wind direction (05103 RM Young), and atmospheric pressure (CS106, Campbell Scientific) were measured at both 2 and $5 \mathrm{~m}$ from the soil surface. Rainfall (CS-700 L, Campbell Scientific) was measured approximately $5 \mathrm{~m}$ from the soil surface.

During each cropping season, daily soil evaporation was observed over a 15-day period in spring-summer (June-July), summer (August-September), and fall (October) with microlysimeter measurements for a total of 90 observations. Then, a multiple linear regression $E=0.015 \cdot T_{a}+0.025 \cdot \mathrm{SWC}-0.63\left(R^{2}=0.78\right)$ was developed to estimate daily soil evaporation $(E, \mathrm{~mm})$ throughout the year from air temperature $\left(T_{a},{ }^{\circ} \mathrm{C}\right)$ and soil water content at $15 \mathrm{~cm}$ of depth (SWC, mm). Small undisturbed soil samples were located in the microlysimeters-rings of limited height that were closed at the bottom-and were weighted and reinstalled in the field. Microlysimeters made from 3-mm-thick aluminum pipe were $12.5-\mathrm{cm}$-long with a diameter of $11.5 \mathrm{~cm}$. A portable electronic balance was used to weigh daily the microlysimeters at approximately 0830 local standard time (LST) (Han and Felker 1997). Five microlysimeters were placed between the row and five were placed under the plant canopy. Soil cores in the 10 microlysimeters were replaced every day.

Canopy surface temperature $\left(T_{c}\right)$ (i.e., air temperature at the surface canopy) was determined as outlined by Adams et al. (1991)

$$
T_{c}=T_{a}+\frac{H}{\rho C_{p} g_{a}}
$$

where $T_{a}\left({ }^{\circ} \mathrm{C}\right)=$ air temperature $H\left(\mathrm{~W} \mathrm{~m}^{-2}\right)=$ sensible heat flux estimated by the SR method and calibrated with the EC technique; $\rho=$ density $\left(\mathrm{kg} \mathrm{m}^{-3}\right)$ of air; $C_{p}\left(\mathrm{~J} \mathrm{~kg}^{-1}{ }^{\circ} \mathrm{C}^{-1}\right)=$ specific heat of the air; and $g_{a}\left(\mathrm{~m} \mathrm{~s}^{-1}\right)=$ aerodynamic conductance for water vapor.

Cladode temperature was measured with temperature sensors (HOBO H-08, Onset, Bourne, Massachusetts) inserted in the parenchyma of two either fully exposed or shaded [30\% of the daily photosynthetic photon flux (PPF)] 1-year-old terminal cladodes placed in the canopies of two different trees $(2$ trees $\times$ 2 positions within the tree $\times 2$ cladodes $\times$ position). Data on 
cladode temperature during the monitoring periods were used to estimate the heat storage by cactus (Misc.) in Eq. (5).

The conductance approach based on the Penman equation (Monteith 1965) was applied for comparative analysis of the processes controlling the transfer of energy. The aerodynamic conductance for water vapor $\left(g_{a}\right)$ was calculated from wind data as

$$
g_{a}^{-1}=\frac{u}{u^{*}}+\frac{1}{k u^{*}}\left(\ln \frac{Z_{0}}{Z_{H}}+\Psi_{m}-\Psi_{H}\right)
$$

where $u\left(\mathrm{~m} \mathrm{~s}^{-1}\right)=$ horizontal wind speed as measured at the reference height above the surface; $u^{*}\left(\mathrm{~m} \mathrm{~s}^{-1}\right)=$ friction velocity as measured by the eddy covariance system; $k=$ von Karman's constant; and $Z_{0} / Z_{L}=$ ratio of the surface roughness parameter $(\mathrm{m})$ for momentum $\left(Z_{0}\right)$ and heat $\left(Z_{H}\right)$ transfers (Verma 1989). The $Z_{0} / Z_{L}$ was taken as 10 , a typical value for fairly homogeneous canopy (Garrat and Hicks 1973), and $\psi_{M}$ and $\psi_{H}$ were the adiabatic correction factors for momentum and heat, respectively (Paulson 1970). These were calculated with the Businger-Dyer formulations (Sugita and Brutsaert 1990) for unstable atmospheric conditions (Businger 1988).

\section{Results}

\section{Monitoring Surface Energy Fluxes}

Total rainfall during the irrigation period, which occurred from June-September, was $120 \mathrm{~mm}$ in 2009 and $95 \mathrm{~mm}$ in 2010, whereas previous rainfall in winter and spring was twice as much in 2010 (354 mm) than in 2009 (178 $\mathrm{mm}$ ) (Table 1). The meteorological pattern in the summer periods 2009 and 2010 were associated with high temperatures, humid font, and low precipitation regime, characteristic of the semiarid Mediterranean climate of the region (Table 1). During the active growth period for cactus pear fruit and new cladodes (May-October), the reference evapotranspiration [ET 0 of Eq. (5)], was approximately twofold higher than the cumulative rainfall. Average monthly temperatures in both years were lowest in February and highest in July and August (Table 1).
During the consecutive seasons, the precipitation distribution led to low changes in soil water content $(\theta)$ because of the soil's high water holding capacity $(35.7 \%$ of field capacity and approximately $20 \%$ of soil water available). During the dry seasons, the seasonal average daily $\theta$ measured with TDR probes was slightly below the field capacity; however, the water losses from the soil profile decreased with increasing soil depth (going from 0.15 to $0.60 \mathrm{~m}$ ). The intermitted irrigations recharged the soil profile (from 0.4 to $0.15 \mathrm{~m}$ of depth from the surface) to field capacity. The seasonal average daily soil evaporation was $26 \%$ of $\lambda E$, corresponding to approximately $0.64 \mathrm{~mm} \mathrm{~d}^{-1}$. In Fig. 2, the correspondence between soil water content changed along the monitored profile, and daily soil evaporation and irrigation rates were presented; data referring to the June-September 2009 period were quite similar to those during the same period in 2010.

The turbulent sensible heat fluxes $(H)$ and the available energy (i.e., $R_{n}-G$ ) within the soil-tree-atmosphere continuum system were determined simultaneously, and slight differences between the 2 years of monitoring were detected. In particular, during the cactus growing period (June-September) in 2009, daily soil heat flux density $(G)$ was generally close to zero. Daily $H$ decreased from 8.3 during late June to $-1.5 \mathrm{MJ} \mathrm{m}^{-2} \mathrm{~d}^{-1}$ in September, with a mean value of $5.4 \mathrm{MJ} \mathrm{m}^{-2} \mathrm{~d}^{-1}$ throughout the period. Latent heat flux density $(\lambda E)$ averaged $6.0 \mathrm{MJ} \mathrm{m}^{-2} \mathrm{~d}^{-1}$, ranging between 11.3 and $0.3 \mathrm{MJ} \mathrm{m}^{-2} \mathrm{~d}^{-1}$. Mean value of daily net radiation $\left(R_{n}\right)$ reached approximately $13.0 \mathrm{MJ} \mathrm{m}^{-2} \mathrm{~d}^{-1}$ (Fig. 3). The heat storage by plant had a mean of $1.9 \mathrm{MJ} \mathrm{m}^{-2} \mathrm{~d}^{-1}$, with a peak of $2.7 \mathrm{MJ} \mathrm{m}^{-2} \mathrm{~d}^{-1}$ during the monitored period. In 2010, mean daily $G$ was close to zero, $H$ varied from $8.9 \mathrm{MJ} \mathrm{m}^{-2} \mathrm{~d}^{-1}$ in June to $0.5 \mathrm{MJ} \mathrm{m}^{-2} \mathrm{~d}^{-1}$ in September with a mean of $6.2 \mathrm{MJ} \mathrm{m}^{-2} \mathrm{~d}^{-1}$, and $\lambda E$ averaged $5.0 \mathrm{MJ} \mathrm{m}^{-2} \mathrm{~d}^{-1}$, varying between 10.9 and $-0.18 \mathrm{MJ} \mathrm{m}^{-2} \mathrm{~d}^{-1}$. Misc. had an average of $1.7 \mathrm{MJ} \mathrm{m}^{-2} \mathrm{~d}^{-1}$, varying between 2.7 and $0.16 \mathrm{MJ} \mathrm{m}^{-2} \mathrm{~d}^{-1}$ throughout the period. Daily net radiation $\left(R_{n}\right)$ reached a maximum of $17.4 \mathrm{MJ} \mathrm{m}^{-2} \mathrm{~d}^{-1}$, a minimum of $3.3 \mathrm{MJ} \mathrm{m}^{-2} \mathrm{~d}^{-1}$, and had an average of 13.4 $\mathrm{MJ} \mathrm{m}^{-2} \mathrm{~d}^{-1}$ (Fig. 4).

Daily mean of the evaporative fraction $E_{F}=\lambda E /\left(R_{n}-G\right)$ ) during summer was around $45 \%$, which characterizes the partition of the energy budget at the daily time scale; the temporal variability of the available energy $\left(R_{n}-G\right)$ partitioning, expressed in terms of standard deviation of daily $E_{F}$, had a maximum of $20 \%$.

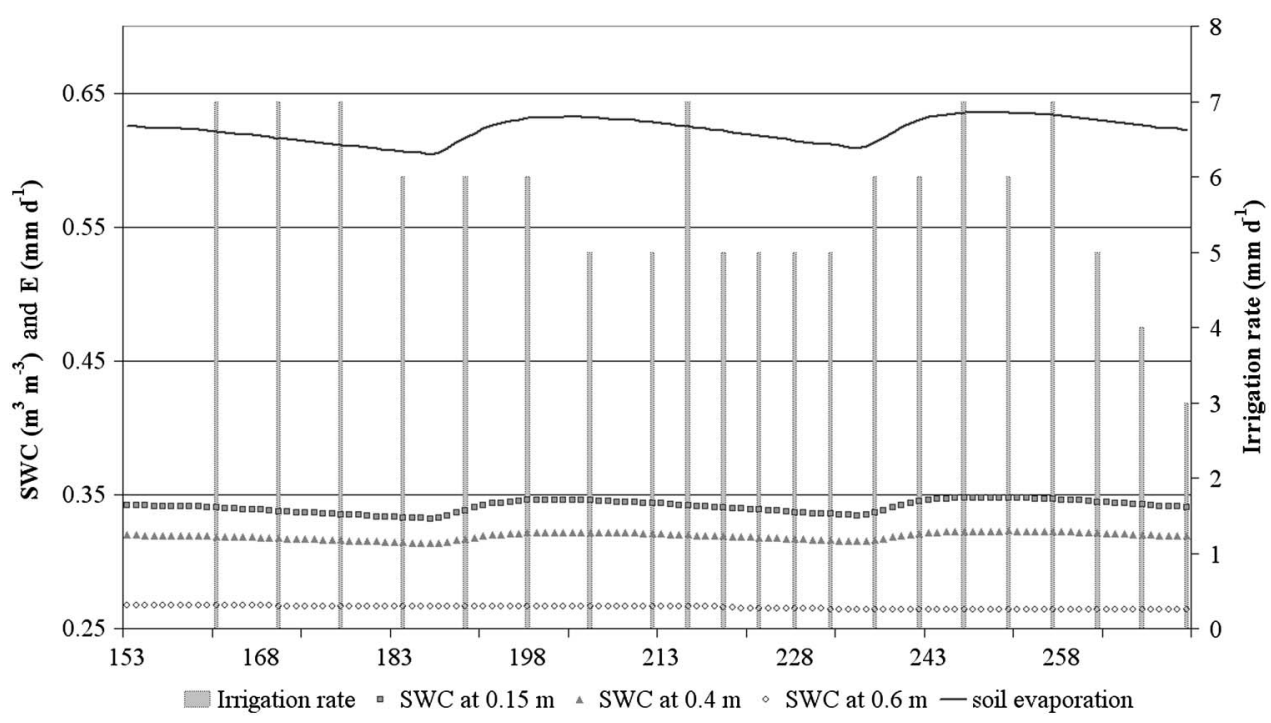

Fig. 2. Soil evaporation and soil water content changes related to irrigation water supply during June-September 2009 


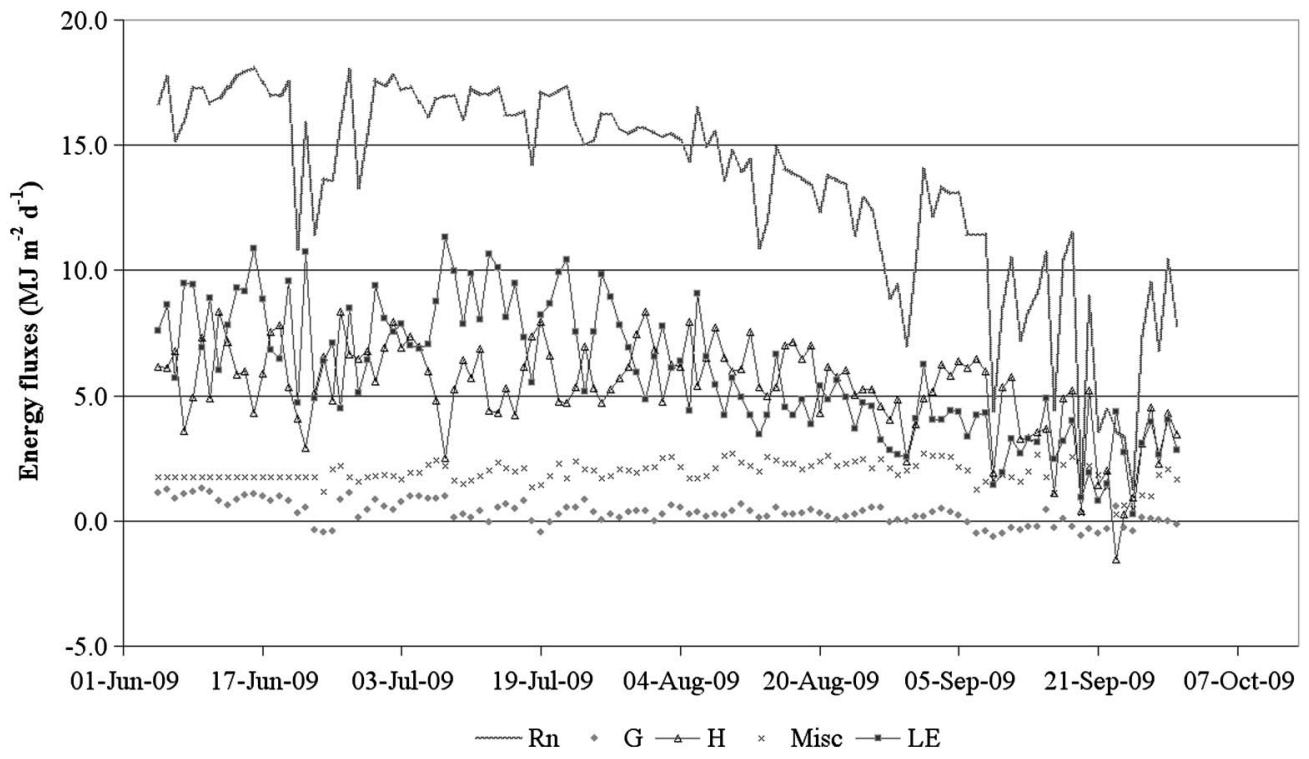

Fig. 3. Daily values of energy balance components $\left(R_{n}=\right.$ net radiation; $G=$ soil heat flux; $H=$ sensible heat flux; Misc $=$ heat storage; $L E=$ latent heat flux) in a cactus pear (Opuntia ficus-indica) orchard, grown for fruit production in Sicily, Italy during June-September 2009

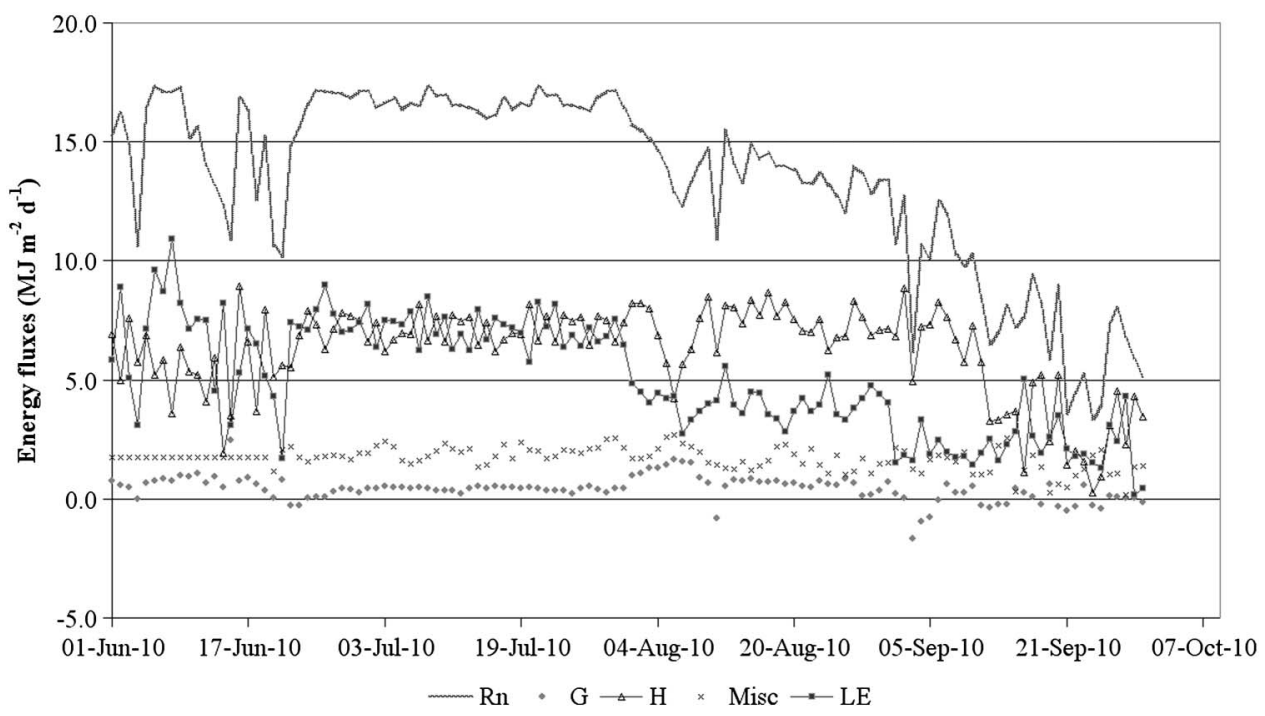

Fig. 4. Daily values of energy balance components $\left(R_{n}=\right.$ net radiation; $G=$ soil heat flux; $H=$ sensible heat flux; Misc $=$ heat storage; $L E=$ latent heat flux) in a cactus pear (Opuntia ficus-indica) orchard, grown for fruit production in Sicily, Italy during June-September 2010

During stable atmospheric conditions, when the available energy $\left(R_{n}-G\right)$ was negative (from around sunset to sunrise), all the fluxes were generally small, and ramp amplitude from SR was not well-formed or not in accordance with the sign of $H_{\mathrm{EC}}$. During the stable case, when $R_{n}-G$ was positive (in late afternoon until around sunrise), air temperature tended to the dew point because of the high relative humidity ( $\mathrm{RH}$ higher than $90 \%)$ values.

The values of $H_{\mathrm{EC}}$ and $H_{\mathrm{SR}}$ were rather well correlated $\left(R^{2}=0.92\right)$ considering the different amount of small eddies (much higher close to the canopy top) that cannot be properly sampled by sonic anemometer, and the $\alpha$ value for unequal heating was of 0.58 (Fig. 5). The $H_{\mathrm{EC}}$ and $H_{\mathrm{SR}}$ data were normally distributed according to the performed $z$-score test. In particular, most outcomes were within 3 standard deviations of the mean.
For low net radiation $\left(<250 \mathrm{~W} \mathrm{~m}^{-2}\right)$, the slope of the relationships between sensible heat flux and net radiation was similar to that of soil heat flux and net radiation. However, the slopes increased and the data were more scattered when net radiation was higher. In fact, the atmospheric sensible heat flux increased more rapidly because under unstable conditions, convection was more efficient in transferring sensible heat from a strong radiative input.

Daily values of $\mathrm{ET}_{0}$ and $\mathrm{ET}_{c}$ were plotted together with $K_{c}$ values for the cactus pear stand during the study periods (Figs. 6 and 7). Average values of the crop coefficient during 2009 were of $0.48,0.49,0.35$, and 0.34 in the June, July, August, and September periods, respectively. In $2010, K_{c}$ values during the same period were $0.48,0.50,0.28$, and 0.25 . Finally, during the 2009 irrigation season, average daily values of $\mathrm{ET}_{c}$ and $\mathrm{ET}_{0}$ were of 2.4 and 


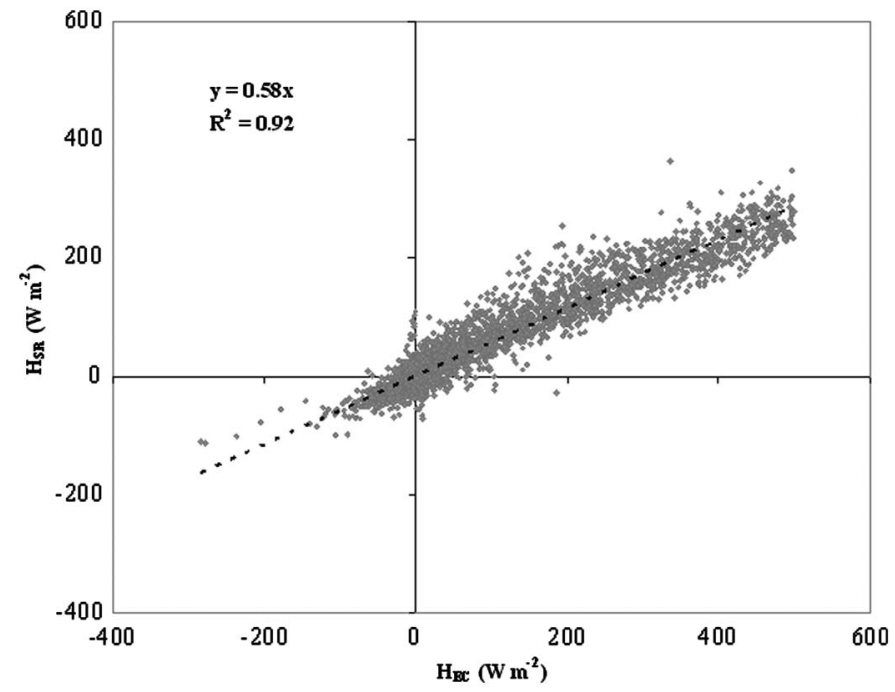

Fig. 5. Sensible heat flux estimates using $\mathrm{SR}$ analysis, $H_{\mathrm{SR}}$, versus the measured using the EC method, $H_{\mathrm{EC}}$; data refer to $n=5,128$ samples
$5.6 \mathrm{~mm}$, respectively, with a corresponding mean value of crop coefficient of 0.42 . In 2010, mean daily $\mathrm{ET}_{c}$ and $\mathrm{ET}_{0}$ were of 2.1 and 5.3 , respectively, with a mean $K_{c}$ of 0.38 .

Differences were found between canopy surface temperature $T_{c}$ and cladode temperature measured in the inner parenchyma tissue. In particular, fully exposed terminal cladodes internal temperatures reached maximum values of $49.8^{\circ} \mathrm{C}$ with a daily mean of $28^{\circ} \mathrm{C}$. The partially exposed (30\% of the daily PPF) young cladodes had a maximum temperature of $36.7^{\circ} \mathrm{C}$, with a mean of $26^{\circ} \mathrm{C}$. A fairly slow variation in the internal temperature was registered in terminal cladodes in response to variations in environmental conditions (i.e., air temperature increase); thus, plants may have long times (order of hours) for thermal changes. This fact is consistent with the statement that a certain (not negligible) heat can be store by means of temperature changes.

The pattern of $g_{a}$ showed a clear diurnal rhythm and was partly correlated with that of evaporative demand of the atmosphere $\left(\mathrm{ET}_{0}\right)$ (Fig. 8). Mean value of cacti aerodynamic conductance was of $0.03 \mathrm{~m} \mathrm{~s}^{-1}$, as confirmed by San-Josè et al. (2007a) and White et al. (2008) in their studies.

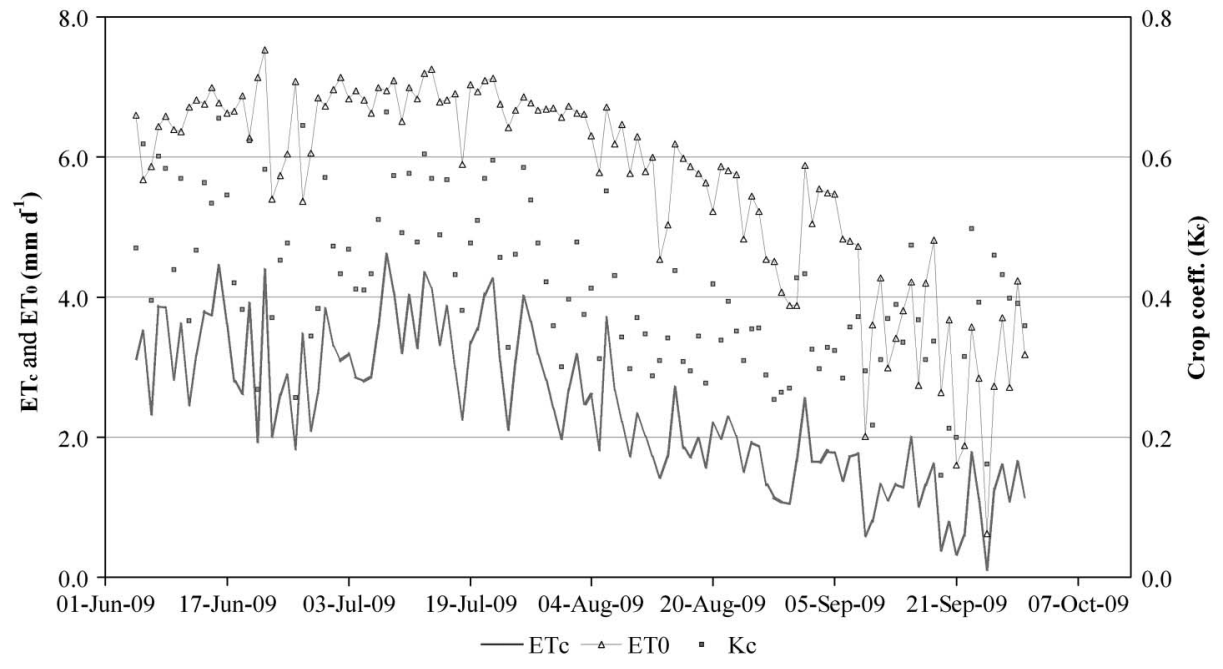

Fig. 6. Daily reference $\left(\mathrm{ET}_{0}\right)$ and crop $\left(\mathrm{ET}_{c}\right)$ evapotranspiration plotted together with $K_{c}$ value in a cactus pear (Opuntia ficus-indica) orchard, grown for fruit production in Sicily, Italy from July-September 2009

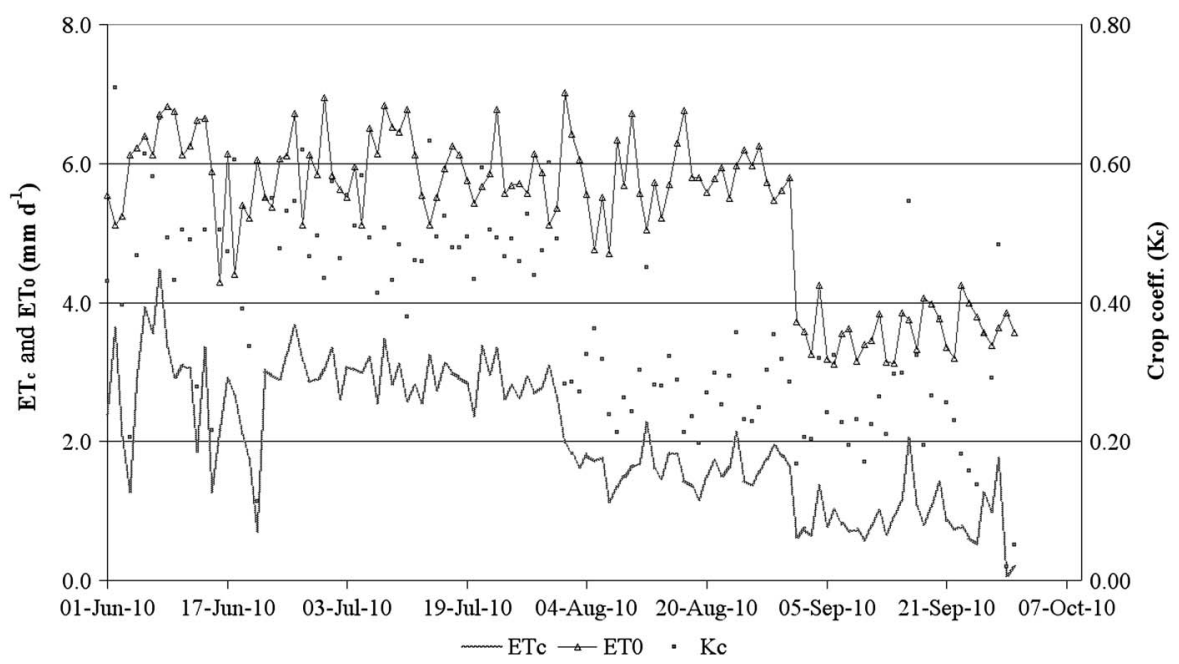

Fig. 7. Daily reference $\left(\mathrm{ET}_{0}\right)$ and crop $\left(\mathrm{ET}_{c}\right)$ evapotranspiration plotted together with $K_{c}$ value in a cactus pear (Opuntia ficus-indica) orchard, grown for fruit production in Sicily, Italy from June-September 2010 


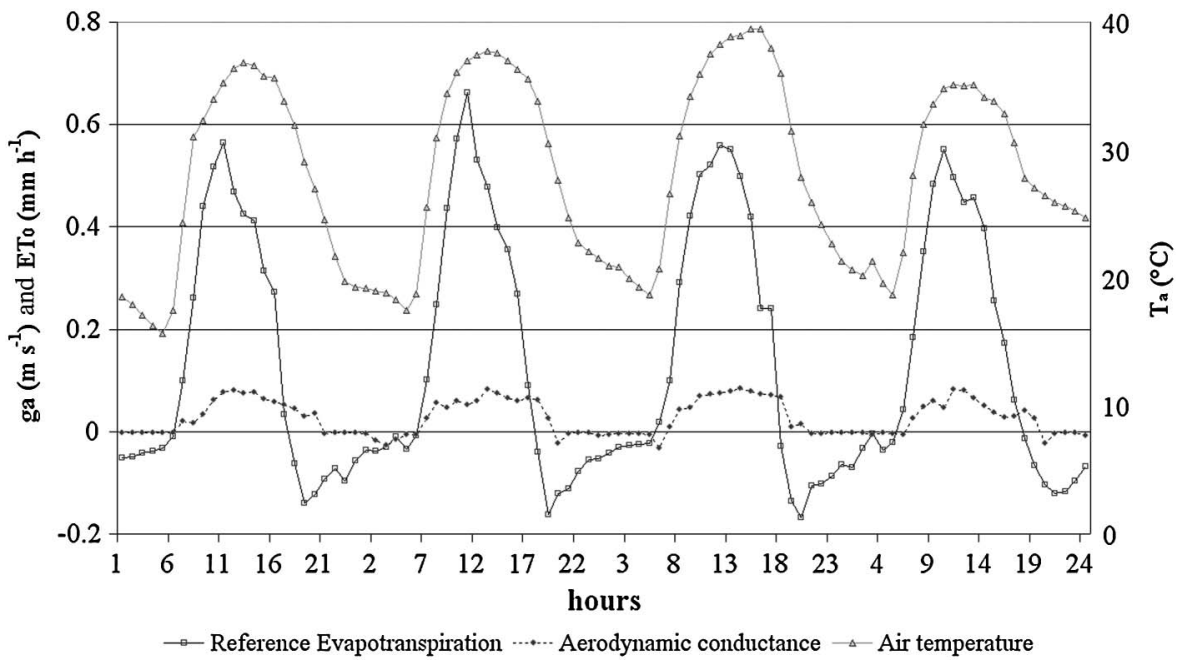

Fig. 8. Hourly values of reference evapotranspiration $\left(\mathrm{ET}_{0}, \mathrm{~mm} \mathrm{~h}^{-1}\right)$, aerodynamic conductance $\left(g_{a}, \mathrm{~m} \mathrm{~s}^{-1}\right)$, and air temperature $\left(T_{a},{ }^{\circ} \mathrm{C}\right)$ in a cactus pear (Opuntia ficus-indica) orchard, grown for fruit production in Sicily, Italy from August 1-4, 2009

\section{Dry Matter Accumulation and Evapotranspiration Water Use Efficiency of Cacti}

During 2009, cactus trees developed $230 \pm 15.3$ new cladodes, representing $16.5 \pm 1.1 \mathrm{~kg}$ of dry weight per tree, which was $41.05 \%$ of the total amount of dry mass fixed. The first flux of flowers was removed to obtain a late crop production; $1,600 \pm 53$ flowers were removed from each tree, for a dry weight (dw) of $2.1 \pm 0.07 \mathrm{~kg}$ tree ${ }^{-1}$. Fruit production following return bloom was $59.8 \pm 1.4 \mathrm{~kg}$ fresh weight tree ${ }^{-1}$, corresponding to $10.2 \pm 0.2 \mathrm{~kg} \mathrm{dw}$, with a total fruit dry mass production of $3.4 \mathrm{tha}^{-1}$, which represents $26.5 \%$ of the total annual aboveground dry mass gained.

Dry matter accumulation in old cladodes was $8.0 \pm$ $0.3 \mathrm{~kg}$ tree ${ }^{-1}$, being $22.1 \%$ of the annual dry matter accumulated. The annual dry mass fixed by a single tree was $38.8 \pm 1.3 \mathrm{~kg}$, which means $13.0 \mathrm{t} \mathrm{dw} \mathrm{ha}{ }^{-1}$ of total aboveground biomass. Seasonal (flowers + fruit + current-year cladode + dry matter gain in older cladodes) dry mass gain was $1.30 \mathrm{~kg} \mathrm{~m}^{-2}$. The photosynthetic area per tree was $104.7 \pm 5 \mathrm{~m}^{2}$. At the end of the season, current-year and 1-year-old cladodes accounted for 28 and $32 \%$, respectively, of the whole tree photosynthetic surface area, and SAI was 3.5.

Total $\mathrm{ET}_{c}$ during June-September 2009 was $286 \mathrm{~mm}$; thus, the obtained evapotranspiration water-use efficiency (WUE $\mathrm{ET}_{\mathrm{ET}}$ ) was $4.6 \mathrm{~g} \mathrm{DM} \mathrm{kg} \mathrm{H}_{2} \mathrm{O}^{-1}$, and the transpiration (calculated as $\mathrm{ET}_{c}$-soil evaporation) ratio $\left(\mathrm{WUE}_{T}\right.$ ) was $6.3 \mathrm{~g} \mathrm{DM} \mathrm{kg} \mathrm{H}_{2} \mathrm{O}^{-1}$. In 2010, $\mathrm{ET}_{c}$ total was $252 \mathrm{~mm}$, and considering the same aboveground dry mass gain as in 2009 (trees are at a mature stage and regularly pruned to maintain allotted space and height, with no alternate bearing behavior), WUE $\mathrm{ET}_{\mathrm{ET}}$ was $4.4 \mathrm{~g} \mathrm{DM} \mathrm{kg} \mathrm{H}_{2} \mathrm{O}^{-1}$ and $\mathrm{WUE}_{T}$ was $5.7 \mathrm{~g} \mathrm{DM} \mathrm{kg} \mathrm{H}_{2} \mathrm{O}^{-1}$.

\section{Discussion}

In this study, the SR method results in fairly accurate estimation of sensible heat fluxes $(H)$ from the cactus pear orchard. A wide literature tends to confirm the suitability of the method applied to estimate $H$ over different crop canopies, such as wheat (Castellví 2004) and maize (Paw U et al. 1995), walnut (Paw U et al. 1995), grapevine, avocado (Paw U et al. 2005), and orange (Consoli et al. 2006) orchards.
The SR method, combined with surface energy balance, results in a valid alternative to techniques based on soil or plant water content that are often difficult to operate for irrigation scheduling in such a succulent species; furthermore, the relatively low-cost SR method provides an excellent approach for estimating crop water requirement in cactus pear.

With respect to a study on SR application over orange orchards (Consoli et al. 2006) with comparable canopy coverage and growth in an area with similar environmental conditions in terms of evaporative demand of the atmosphere, this study on cactus pear indicates lower transpiration rates, evidencing the role of the specie to control the partition of the available energy into sensible and latent heat fluxes.

The daily ET pattern, which derives from the resolution of the energy balance and not from a direct measurement of plant transpiration rate, showed significant values of water vapor condensation attributable to a high air relative humidity and temperatures approaching the dew point almost every night.

Large differences in daily transpiration rates usually occur between dry and wet conditions for O. ficus-indica. Most (90\%) daily transpiration of cactus pear cladodes in well-watered plants occurs during the night time; transpiration rates increase approximately $2 \mathrm{~h}$ before sunset to reach a maximum of $1.1 \mathrm{mmol} \mathrm{m}^{-2} \mathrm{~s}^{-1}$ at midnight (Goldstein et al. 1991). Considering a daily average transpiration rate of $0.3 \mathrm{mmol} \mathrm{m}^{-2} \mathrm{~s}^{-1}$ (Goldstein et al. 1991) and a measured canopy surface area of $3.5 \times 10^{4} \mathrm{~m}^{2}$, an orchard daily transpiration of $1.8 \mathrm{~mm} \mathrm{H}_{2} \mathrm{O}$ can be predicted. Soil evaporation measured along with the season was $0.64 \mathrm{~mm} \mathrm{~d}^{-1}$, giving a total ET of $2.44 \mathrm{~mm} \mathrm{~d}^{-1}$. This perfectly matches the values derived from the application of the energy balance.

The $K_{c}$ values found in the present work are similar to those reported for olive (Olea europaea L.) in Mediterranean environments (Fernàndez et al. 2006) and show little seasonal variability, reaching their maximum when the canopy surface area is fully developed.

The available water resulting from irrigation and rainfall occurred during the irrigation period was $240 \mathrm{~mm}$, equal to $85 \%$ of $\mathrm{ET}_{c}$, in summer 2009 and $185 \mathrm{~mm}$, equal to $73 \%$ of $\mathrm{ET}_{c}$, in summer 2010. Nevertheless, fruit size did not change, fruit crop was $18 \mathrm{tha}^{-1}, 80 \%$ of fruits reached export size (120 g), and trees never showed any evidence of water stress. Indeed, winter and spring rainfall were, in both years, high enough to allow a large 
water storage in the succulent cladodes of the trees, and this may play a substantial role in the response of the trees to irrigation and to a relatively small water deficit in summer.

The WUE values calculated in this work are similar to those reported in literature; De Kock (1980) measured, for South African $O$. ficus-indica plantations for forage production, WUE values of $4.0 \mathrm{~g} \mathrm{DM} \mathrm{kg}^{-1} \mathrm{H}_{2} \mathrm{O}\left(250 \mathrm{~kg} \mathrm{H}_{2} \mathrm{O} \mathrm{Kg}^{-1} \mathrm{DM}\right)$; and $\mathrm{Le}$ Houèrou (2000), in North Africa, indicated WUE values of $3.2 \mathrm{~g} \mathrm{DM} \mathrm{kg}^{-1} \mathrm{H}_{2} \mathrm{O}$ (300 $\left.\mathrm{kg} \mathrm{H}_{2} \mathrm{O} \mathrm{Kg}^{-1} \mathrm{DM}\right)$ for $O$. ficus-indica rain-fed plantations for forage production. Han and Felker (1997) in south Texas found WUE values of $6.2 \mathrm{~g} \mathrm{DM} \mathrm{kg}^{-1} \mathrm{H}_{2} \mathrm{O}$ (166 kg $\mathrm{H}_{2} \mathrm{O} \mathrm{Kg} \mathrm{Kg}^{-1} \mathrm{DM}$ ) for O. ellissiana.

O. ficus-indica requires a SAI of approximately 4 for high biomass gain (De Cortázar and Nobel 1986). Han and Felker (1997) reported an annual dry biomass productivity of $O$. ellisiana of $17.6 \mathrm{t} \mathrm{ha}^{-1}$ year $^{-1}$ with a SAI of 4 . Greater values were reported by Nobel $(1991,1992)$ for high-density O. ficus-indica plantings, with productivities of 47 and $45 \mathrm{t} \mathrm{ha}^{-1}$ year $^{-1}$, respectively. De Cortázar and Nobel (1992) showed even higher productions of $49.8 \mathrm{t} \mathrm{ha}^{-1}$ year $^{-1}$ dry mass in a 3-year-old $O$. ficus-indica plot with 240,000 plants ha $^{-1}$. All the values cited previously were obtained with no concern to fruit size and quality parameters.

The canopy surface area, during 2009, increased by $30 \%$ because of the growth of a high number of current-year cladodes.

The proportion of annual dry matter allocated to the fruit component (harvest index, $\mathrm{HI}$ ) was $25 \%$, corresponding to more than $18 \mathrm{tha}^{-1}$ of high-quality fruit.

Commercial SAI is very similar to values indicated by Nobel (1988), and close to values adopted in the temperate zone systems for fruit production (Faust 1989). Liguori et al. (2009), in a 14-yearold Tarocco orange orchard, spaced $4.5 \times 4.5 \mathrm{~m}$ apart, with a fruit yield of $35 \mathrm{tha}^{-1}$ year $^{-1}$ and a 3.5 leaf area index (LAI), reported an annual dry matter fixation of $11.7 \mathrm{tha}^{-1}$. A 4-year-old peach orchard (Prunus persica L. Batsch Flordaprince on GF 677 rootstock) trained to a free-standing central leader 930 trees ha ${ }^{-1}$ with a 5.4 LAI, fixed $15.7 \mathrm{t}$ dry matter $\mathrm{ha}^{-1}$, and an $\mathrm{HI}$ of $17.2 \%$ (Caruso et al. 1999). A 7-year-old Lambert sweet cherry orchard (474 trees ha ${ }^{-1}$ ) fixed $6.3 \mathrm{t}$ dry matter ha ${ }^{-1}$ with a $1.4 \mathrm{LAI}$ and an HI of 15\% (Kappel 1991). An 8-year-old McIntosh/MM106 apple orchard (Malus domestica Borkh.) trained to a modified central leader, fixed $20.7 \mathrm{t}$ dry matter $\mathrm{ha}^{-1}$ year $^{-1}$ and a LAI of 4.1 (Forshey et al. 1983).

Ultimately, cactus pear orchards for fruit production coupled the ability of using a limited water resource base with the efficiency of the system both in terms of water use efficiency and dry matter diverted to the fruit component.

\section{Conclusions}

Surface renewal was useful and effective to measure the actual evapotranspiration over the canopy of the CAM O. ficus-indica orchard. The relatively low-cost SR method was able to detect the role of the species in controlling the available energy partition between different flux densities $(H, G)$, providing an excellent approach to obtain evapotranspiration information for irrigation scheduling.

The use of crop $K_{c}$ for cactus pear is suggested to reduce water use without reducing crop yield and quality because of proper irrigation scheduling.

Further studies may relate the physiological status of the plant with micrometeorological information (e.g., gas exchange rate or fruit growth rate pattern versus energy balance). Moreover, deficit irrigation (DI) strategies should be studied and applied to
O. ficus-indica. Deficit irrigation is currently applied to different fruit trees (Chalmers et al. 1981; Mpelasoka et al. 2001; Moriana et al. 2003) with 60-70\% ETc restitutions. In any case, growth and ultimate fruit size are affected by water deficit long before any other plant response is apparent; this makes very difficult the irrigation management in relation to fruit quality.

\section{References}

Acevedo, E., Badilla, I., and Nobel, P. S. (1983). "Water relations, diurnal acidity changes, and productivity of a cultivated cactus, Opuntia ficus-indica." Plant Physiol., 72(3), 755-780.

Adams, R. S., Black, T. A., and Fleming, R. L. (1991). "Evapotranspiration and surface conductance in a high elevation, grass-covered forest clearcut." Agric. For. Meteorol., 56(3-4), 173-193.

Allen, R. G., Pereira, L. S., Raes, D., and Smith, M. (1998). "Crop evapotranspiration: Guidelines for computing crop water requirements." $F A O$ Irrigation and Drainage Paper 56, Food and Agricultural Organization of the U.N., Rome.

Allen, R. G., et al. (2006). "A recommendation on standardized surface resistance for hourly calculation of reference ET0 by the FAO56 Penman-Monteith method." Agric. Water Manage., 81(1-2), 1-22.

Barbera, G. (1984). "Ricerche sull'irrigazione del Ficodindia." Frutticoltura, 46(8), 49-55.

Businger, J. A. (1988). "A note on the Businger-Dyer profiles." Boundary Layer Meteorol., 42(1-2), 145-151.

Caruso, T., Inglese, P., Sottile, F., and Marra, F. P. (1999). "Effect of planting system on productivity, dry-matter partitioning and carbohydrate content in above-ground components of 'Flordaprince' peach trees." J. Am. Soc. Hort. Sci., 124(1), 39-45.

Castellví, F. (2004). "Combining surface renewal analysis and similarity theory: A new approach for estimating sensible heat flux." Water Resour. Res., 40(5), W05201.

Castellví, F., Consoli, S., and Papa, R. (2012). "Sensible heat flux estimates using two different methods based on surface renewal analysis. A study case over an orange orchard in Sicily." Agric. For. Meteorol., 152, $58-64$.

Chalmers, D. J., Mitchell, P. D., and van Heek, L. (1981). "Control of peach tree growth and productivity by regulated water supply, tree density, and summer pruning." J. Am. Soc. Hort. Sci., 106, 307-312.

Consoli, S., and Barbagallo, S. (2012). "Estimating water requirements of an irrigated Mediterranean vineyard using a satellite-based approach." J. Irrig. Drain. Eng., 138(10), 896-904.

Consoli, S., O'Connell, N., and Snyder, R. L. (2006). "Estimation of evapotranspiration of different-sized navel-orange tree orchards using energy balance." J. Irrig. Drain. Eng., 132(1), 2-8.

De Cortázar, V. G., and Nobel, P. S. (1986). "Modeling of PAR interception and productivity of a prickly pear cactus, Opuntia ficusindica L., at various spacings." Agron. J., 78(1), 80-85.

De Cortázar, V. G., and Nobel, P. S. (1992). "Biomass and fruit production for the prickly pear cactus, Opuntia ficus-indica.” J. Am. Soc. Hort. Sci., 174(4), 558-562.

De Kock, G. C. (1980). "Drought-resistant fodder shrub crops in South Africa." Browse in Africa: The current state of knowledge, H. N. Le Houèrou, ed., International Livestock Centre for Africa, Addis-Ababa, 339-410.

Faust, M. (1989). Physiology of temperate zone fruit trees, Wiley, New York.

Fernàndez, J. E., et al. (2006). "Water relations and gas exchange in olive trees under regulated deficit irrigation and partial rootzone drying." Plant Soil, 284(1-2), 273-291.

Foken, T. (2008). Micrometeorology, Springer Verlag, Germany.

Forshey, C. G., Weires, R. W., Stanley, B. H., and Seem, R. C. (1983). "Dry weight partitioning of 'McIntosh' apple trees." J. Am. Soc. Hort. Sci., 108(1), 149-154.

Fuchs, M., and Tanner, C. B. (1967). "Evaporation from drying soil." J. Appl. Meteorol., 6(5), 852-857. 
Garrat, J. R., and Hicks, B. B. (1973). "Momentum, heat and water vapour transfer to and from natural and artificial surfaces." $Q$. J. R. Meteorol. Soc., 99(422), 680-687.

Goldstein, G., Ortega, J. K. E., Nerd, A., and Nobel, P. S. (1991). "Diel patterns of water potential components for the crassulacean acid metabolism plant Opuntia ficus-indica when well-watered or droughted." Plant Physiol., 95(1), 274-280.

Gugliuzza, G., Inglese, P., and Farina, V. (2002). "Relationship between fruit thinning and irrigation on determining fruit quality of cactus pear fruits." Acta Hortic., 581, 221-225.

Han, H., and Felker, P. (1997). "Field validation of water-use efficiency of the CAM plant Opuntia ellisiana in south Texas." J. Arid. Environ., 36(1), 133-148.

Higbie, R. (1935). "The rate of absorption of a pure gas into a still liquid during short periods of exposure." Trans. Am. Inst. Chem. Eng., 31, 355-388.

Inglese, P., Barbera, G., and La Mantia, T. (1999). "Seasonal reproductive and vegetative growth patterns and resource allocation during cactus pear fruit growth." J. Am. Soc. Hort. Sci., 34(1), 69-72.

Jarvis, P. G., and McNaughton, K. G. (1986). "Stomatal control of transpiration: Scaling up from leaf to region." Adv. Ecol. Res., 15, 1-49.

Kaimal, J. C., and Finningan, J. J. (1994). Atmospheric boundary layer flows. Their structure and measurement, Oxford University Press, New York.

Kappel, F. (1991). "Partitioning of above-ground dry matter in "Lambert" sweet cherry trees with or without fruit." J. Amer. Soc. Hort. Sci., (116), 201-205.

Keller, D., and Karmeli, J. (1975). Trickle irrigation design, Rain Bird, Glendora, CA.

Klute, A., Dirksen, C. (1986). "Hydraulic conductivity and diffusivity: Laboratory methods." Chapter 28, Methods of soil analysis. Part 1, physical and mineralogical methods, 2nd Ed., A. Klute, ed., American Society of Agronomy, Madison, WI, 687-734.

Le Houèrou, H. N. (2000). "Cacti (Opuntia spp.) as a fodder crop for marginal lands in the Mediterranean basin." Acta Hortic., 581, 21-46.

Liguori, G., Gugliuzza, G., and Inglese, P. (2009). "Evaluating carbon fluxes in orange orchards in relation to planting density." J. Agric. Sci., 147(6), 637-645.

Mauder, M., and Foken, T. (2004). "Documentation and instruction manual of the eddy covariance software package TK2." Universität Bayreuth, Abt. Mikrometeorologie, Arbeitsergebnisse, 26-44.

Meijninger, W. M. L., and de Bruin, H. A. R. (2000). "The sensible heat fluxes over irrigated areas in western Turkey determined with a large aperture scintillometer." J. Hydrol., 229(1-2), 42-49.

Monteith, J. L. (1965). "Evaporation and environment." The State and Movement of Water in Living Organism. Proc., XIX Symp. of the Society for Experimental Biology, G. E. Fogg, ed., Cambridge University Press, UK, 205-234.

Moriana, A., Orgaz, F., Pastor, M., and Fereres, E. (2003). "Yield responses of mature olive orchard to water deficits." J. Am. Soc. Hort. Sci., 128(3), 425-431.

Mpelasoka, B. S., Behboudian, M. H., and Green, S. R. (2001). "Water use, yield and fruit quality of lysimeter-grown apple trees, responses to deficit irrigation and to crop load." Irrig. Sci., 20(3), 107-113.

Mualem, Y. (1986). "Hydraulic conductivity of unsaturated soils: Prediction and formulas." Methods of soil analysis, Part 1, physical and mineralogical methods, 2nd Ed., A. Klute, ed., American Society of Agronomy, Madison, WI, 799-823.

Nerd, A., Karady, A., and Mizrahi, Y. (1989). "Irrigation, fertilization and polyethylene covers influence bud development in prickly pear." Hortic. Sci., 24(5), 773-775.

Nobel, P. S. (1988). Environmental biology of agaves and cacti, Cambridge University Press, Cambridge, NY.
Nobel, P. S. (1991). "Achievable productivities of certain CAM plants: Basis for high values compared with $\mathrm{C} 3$ and C4 plants." New Phytol., 119(2), 183-205.

Nobel, P. S. (1992). "High annual productivity of certain agaves and cacti under cultivation." Plant Cell Environ., 15(3), 329-335.

Nobel, P. S. (2002). Cacti: Biology and uses, University of California Press, Berkeley, CA.

Nobel, P. S. (2005). Physicochemical and environmental plant physiology, 3rd Ed., Elsevier Academic, Burlington, MA.

Nobel, P. S., and Bobich, E. (2002). "Initial net $\mathrm{CO}_{2}$ uptake responses and root growth for a CAM community placed in a closed environment." Ann. Bot., 90(5), 593-598.

Nobel, P. S., and Hartsock, T. L. (1984). "Physiological responses of Opuntia ficus-indica to growth temperature." Physiol. Plant., 60(1), 98-105.

Paulson, C. A. (1970). "The mathematical representation of wind speed and temperature profile in the unstable surface layer." J. Appl. Meteorol. Climatol., 9(6), 857-861.

Paw U, K. T., Qui, J., Su, H. B., Watanabe, T., and Brunet, Y. (1995). "Surface renewal analysis: A new method to obtain scalar fluxes without velocity data." Agric. For. Meteorol., 74(1-2), 119-137.

Paw U, K. T., Snyder, R. L., Spano, D., and Su, H. B. (2005). "Surface renewal estimates of scalar exchanges." Chapter 20, Micrometeorology in agricultural systems, agronomy monograph 47, ASA-CSSA-SSSA, Madison, WI.

San José, J. J., Montes, R., and Nikonova, N. (2007a). Diurnal patterns of carbon dioxide, water vapour and energy fluxes in pineapple [Ananas comosus (L.) Merr. Cv. Red Spanish] field using eddy covariance." Photosynthetica, 45(3), 370-384.

San José, J. J., Montes, R., and Nikonova, N. (2007b). "Seasonal patterns of carbon dioxide, water vapour and energy fluxes in pineapple." Agric. For. Meteorol., 147(1-2), 16-34.

Simmons, L. J., Wang, J., Sammis, T. W., and Miller, D. R. (2007). “An evaluation of two inexpensive energy-balance techniques for measuring water use in flood-irrigated pecans (Carya illinoinensis)." Agric. Water Manage., 88(1-3), 181-191.

Snyder, R. L., Spano, D., and Paw U, K. T. (1996). "Surface renewal analysis for sensible and latent heat flux density." Boundary Layer Meteorol., 77(3-4), 249-266.

Snyman, H. A. (2006). "Root distribution with changes in distance and depth of two-year-old cactus pears Opuntia ficus-indica and $O$. robusta plants." S. Afr. J. Bot., 72(3), 434-441.

Soil Conservation Service (SCS). (1982). "Procedures for collecting soil samples and methods of analysis for soil survey." Soil survey investigation Rep. 1, USDA, Washington, DC.

Spano, D., Snyder, R. L., Duce, P., and Paw U, K. T. (1997). "Surface renewal analysis for sensible heat flux density using structure functions." Agric. For. Meteorol., 86(3-4), 259-271.

Sugita, M., and Brutsaert, W. (1990). "Regional surface fluxes from remote sensed surface skin temperature and lower boundary layer measurements." Water Resour. Res., 26(12), 2937-2944.

Van Atta, C. W. (1977). "Effect of coherent structures on structure functions of temperature in the atmospheric boundary layer." Arch. Mech., 29, $161-171$.

Van Genuchten, M. T. (1980). "A closed-form equation for predicting the hydraulic conductivity of unsaturated soils." Soil Sci. Soc. Am. J., 44(5), 892-898.

Verma, S. B. (1989). "Aerodynamic resistance to transfer of heat, mass and momentum." Estimation of areal evapotranspiration, T. A. Black, D. L. Spittlelhouse, M. D. Novak, and D. T. Price, eds., International Association of Hydrological Science, Wallingford, UK, 13-20.

White, J. D., Gutzwiller, K. J., Barrowb, W. C., Randallb, L. J., and Swinta, P. (2008). "Modeling mechanisms of vegetation change due to fire in a semi-arid ecosystem." Ecol. Eng., 214(2-4), 181-200. 